\title{
HUBUNGAN KONSUMSI JENIS PANGAN YANG MENGANDUNG INDEKS GLIKEMIK TINGGI DENGAN GLUKOSA DARAH PASIEN DM TIPE 2 DI UPTD DIABETES CENTER KOTA TERNATE
}

\section{(Consumption Relationship Of Food Types Containing High Glycemic Index With Blood Glucose Of Type 2 DM Patients In UPTD Diabetes Center Ternate City )}

\author{
Nizmawaty Amra ${ }^{1^{*}}$ \\ ${ }^{1}$ Dosen Jurusan Gizi Politeknik Kesehatan Kemenkes Ternate, Jalan AM. Kamaruddin Kampus B Siko Kelurahan \\ Sangaji Kota Ternate Maluku Utara 0921-3121870. Email : nonie.amra@gmail.com
}

\begin{abstract}
ABSTRAK
Diabetes Melitus merupakan kelainan metabolik dengan etiologi multifactorial. Prevalensi DM di Indonesia saat ini menempati peringkat ke-5 di dunia, dibandingkan data IDF tahun 2013 yang menempati peringkat ke-7 di dunia dengan 7,6 juta orang. Kunci pokok dalam penatalaksanaan diabetes tipe 2 adalah diet yang benar maka toleransi glukosa dapat menjadi normal. Para ilmuwan menemukan bahwa terjadinya kenaikan kadar glukosa darah dapat diperkirakan dari makanan yang mengandung beberapa jenis pangan dengan indeks glikemik yang berbeda. Penelitian ini bertujuan untuk melihat hubungan konsumsi jenis pangan yang mengandung indeks glikemik tinggi dengan kadar gula darah pasien DM tipe2. Metode penelitian analitik dengan desain cross sectional study dengan 30 responden. Konsumsi jenis pangan yang mengandung indeks glikemik tinggi dengan kadar gula darah puasa tinggi sebanyak 11 orang (10,5\%), hasil analisis chisquare menunjukkan nilai $p=0,69(>0,05)$. Indeks glikemik tinggi dengan kadar gula darah 2 Jam Post Prandial tinggi sebanyak 13 orang (11,0\%), hasil analisis menunjukkan nilai $p=0,09(>0,05)$ dan seluruh subyek memiliki kadar gula darah sewaktu tinggi yaitu 30 orang (100\%) dengan indeks glikemik tinggi dan sedang masing-masing 15 orang (50\%). Tidak ada hubungan konsumsi jenis pangan yang mengandung indeks gliemik tinggi dengan kadar gula darah pasien DM tipe 2 di Diabetes Center Kota Ternate.
\end{abstract}

Kata Kunci : konsumsi jenis pangan, indeks glikemik tinggi, glukosa darah, pasien DM tipe 2

\begin{abstract}
Diabetes mellitus (DM) is a metabolic disorder with multifactorial etiology. Nowadays, DM prevalence in Indonesia is ranked 5th in the world, compared to IDF data in 2013 which is ranked 7th in the world with 7.6 million people. The main key in the management of type 2 diabetes is the proper diet, it result in normal glucose tolerance. The scientists found that an increase in blood glucose levels can be estimated from foods containing several types of food portion with different glycemic indexes. This study aims to know at the relationship between high glycemic index foods consumption and blood glucose of type 2 diabetes patient. Studies using analytical research method with cross sectional study design which is consist of 30 respondents. The result showed that high glycemic index foods consumption with high fasting blood sugar levels as many as 11 people $(10.5 \%)$, the results of the chi-square analysis showed the value of $p=0.69$ (>0.05). Besides, high glycemic index with high postprandial glucose level as many as 13 people (11.0\%), the results of the analysis showed $p=0.09$ (>0.05) and respectively, all subjects had high random glucose levels at 30 people (100\%) and most of people (15) with high and medium glycemic index (50\%).

There is no correlation between high glycemic index foods consumption with blood glucose of type 2 diabetes patient in Diabetes Centre, Ternate City
\end{abstract}

Keywords : Consumption of food types, high glycemic index, blood glucose, type 2 DM patients

\footnotetext{
*Penulis untuk korespondensi: nonie.amra@gmail.com
} 


\section{PENDAHULUAN}

Diabetes Melitus tipe 2 merupakan penyakit multifaktorial dengan komponen genetik dan lingkungan yang memberikan kontribusi sama kuatnya terhadap proses timbulnya penyakit tersebut. Sebagian faktor ini dapat dimodifikasi melalui perubahan gaya hidup, sementara sebagian lainnya tidak dapat diubah. ${ }^{5}$ Indeks Glikemik adalah angka yang menunjukkan potensi peningkatan gula darah dari karbohidrat yang tersedia pada suatu jenis pangan sebagai tingkatan atau rangking pangan menurut efeknya terhadap kadar glukosa darah.Jenisbahan makanan yang cepat menaikkan kadar glukosa darah adalah bahan makanan yang memiliki indeks glikemik tinggi. Konsep indeks glikemik dikembangkan untuk mengurutkan kemampuan jenis bahan makanan dalam meningkatkan kadar glukosa darah yang sangat berguna bagi orang-orang yang mengalami kegagaglan toleransi glukosa. ${ }^{10}$

Berdasarkan data International Diabetes Federation (IDF) Tahun 2014, saat ini diperkiraan 9,1 juta orang penduduk didiagnosis sebagai penyandang DM. Dengan angka tersebut Indonesia menempati peringkat ke-5 di dunia, atau naik dua peringkat dibandingkan data IDF tahun 2013 yang menempati peringkat ke-7 di dunia dengan 7,6 juta orang penyandang DM. ${ }^{7}$ Badan Organisasi Dunia atau WHO memprediksi kenaikan jumlah penyandang DM di Indonesia dari 8,4 juta pada tahun 2000 menjadi sekitar 21,3 juta pada tahun 2030 . Laporan ini menunjukkan adanya peningkatan jumlah penyandang DM sebanyak 2-3 kali lipat pada tahun 2035. Laporan hasil Riset Kesehatan Dasar (Riskesdas) tahun 2007 oleh Departemen Kesehatan, menunjukan bahwa prevalensi diabetes melitus di daerah urban Indonesia untuk usia diatas 15 tahun sebesar 5,7\%. Prevalensi terkecil terdapat di Propinsi Papua sebesar 1,7\% dan terbesar di Propinsi Maluku Utara dan Kalimantan Barat yang mencapai 11,1\%.7

Prevalensi DM pada populasi dewasa di seluruh dunia diperkirakan akan meningkat sebesar $35 \%$ dalam dua dasawarsa dan menjangkiti 300 juta orang dewasa pada tahun 2025. Bagian besar peningkatan angka prevalensi ini akan terjadi di Negara-negara berkembang. ${ }^{5}$ Berdasar data IDF 2014, saat ini diperkiraan 9,1 juta orang penduduk didiagnosis sebagai penyandang DM. Dengan angka tersebut Indonesia menempati peringkat ke-5 di dunia, atau naik dua peringkat dibandingkan data IDF tahun 2013 yang menempati peringkat ke-7 di dunia dengan 7,6 juta orang penyandang DM. ${ }^{7}$

Pokok-Pokok hasil Riset Kesehatan Dasar (Riskesdas) Provinsi Maluku Utara Tahun 2013, menunjukkan prevalensi diabetesi berdasar wawancara yang terdiagnosis dokter sebesar 1,2 persen. Kota Ternate merupakan Kota dengan Prevalensi diabetesi terbesar dibandingkan 9 Kabupaten/Kota di Maluku Utara yaitu 2,9\%. ${ }^{8}$

Pola makan atau diet merupakan determinan penting yang menentukan obesitas dan juga mempengaruhi resistensi insulin. ${ }^{5}$ Prinsip pengaturan makan pada penyandang diabetes hampir sama dengan anjuran makan untuk masyarakat umum yaitu makanan yang seimbang dan sesuai dengan kebutuhan kalori dan zat gizi masing-masing individu. Pada penyandang diabetes perlu ditekankan pentingnya keteraturan makan dalam hal jadwal makan, jenis dan jumlah makanan, terutama pada mereka yang menggunakan obat penurunan glukosa darah atau insuli. ${ }^{8}$ Pasien DM dianjurkan untuk memilih jenis bahan makanan dengan indeks glikemik rendah sehingga tidak cepat menaikan kadar glukosa darah. ${ }^{10}$

\section{METODE}

Data yang dikumpulkan dalam penelitian ini terdiri dari data primer dan data sekunder. Data primer meliputi karakteristik responden, jumlah, jenis makanan dan frekuensi makan subyek. Sedangkan data sekunder adalah jumlah kunjungan responden dan gambaran wilayah penelitian.

Jenis penelitian ini adalah penelitian analitik dengan desain cross sectional study untuk mengetahui hubungan konsumsi makanan yang mengandung Indeks glikemik dengan glukosa darah pada penderita diabetes mellitus. Populasi dalam penelitian adalah seluruh pasien yang berkunjung di UPTD. Diatebes Centre Kota Ternate. Pengambilan sampel pada penelitian ini menggunakan metode consecutive sampling non probability sampling, yang berarti setiap pasien yang memenuhi kriteria penelitian 
dimasukkan dalam penelitian sampai kurun waktu tertentu sehingga jumlah pasien yang diperlukan terpenuhi. Besar sampel dalam penelitian ini adalah 30 responden yang berada di UPTD Diabetes Center yang memenuhi kriteria inklusi diantaranya ; bersedia menjadi responden, pasien yang mengkonsumsi obat dan bertempat tinggal di Wilayah Kota Ternate. Kemudian kriteria eksklusinya adalah pasien dalam keadaan hamil, menderita komplikasi enyakit kronis dan kesulitan dalam berkomunikasi. Variabel penelitian terdiri dari variabel bebas yaitu pasien diabetes mellitus tipe-2 yang berkunjung di diabetes center kota Ternate dan variabel terikat adalah konsumsi jenis makanan yang mengandung indeks glikemik.

Proses pengumpulan data diawali dengan meminta kesediaan dan menandatangi format persetujuan menjadi sampel kemudian, melakukan wawancara untuk mengetahui informasi karakteristik responden dan mencatat hasil wawancara tentang jenis makanan yang dikonsumsi menggunakan food recall selama 3 hari, selanjutnya mencatat hasil pengukuran kadar gula darah sewaktu untuk hari pertama dan pada hari kedua dilakukan pemeriksaan kadar gula darah puasa dan kadar gula darah 2JPP.

Pengolahan data diawali dengan editing untuk mengecek kelengkapan data, coding memudahkan dalam proses entry data, selanjutnya dilakukan entry data. Data konsumsi jenis bahan makanan yang mengandung indeks glikemik dihitung menggunakan komputer.

Analisis dalam bentuk univariat dengan menampilkan data dalam bentuk tabel distribusi frekuensi yang meliputi kadar glukosa dan jenis bahan makanan yang mengandung indeks glikemik. Analisis bivariat menyajikan data dalam bentuk tabel silang meliputi asupan jenis bahan makanan responden. Untuk mengetahui ada hubungan antar variabel digunakan uji statistik chi-square.

\section{HASIL DAN PEMBAHASAN}

Berdasarkan hasil penelitian yang dilakukan di Unit Pelaksana Teknis Daerah (UPTD) Diabetes Center yang merupakan satu-satunya tempat pelayanan kesehatan dasar untuk penderita Diabetes Mellitus yang berada di Kota Ternate. UPTD Diabetes Center dalam perkembangannya mulai dari tahun 2009 terus meningkat, yang bertujuan agar pelayanan dapat dijangkau oleh seluruh masyarakat Kota Ternate.

Tabel 1. Distribusi responden berdasarkan jenis kelamin

\begin{tabular}{|c|c|c|}
\hline Variabel & $\mathrm{n}$ & $\%$ \\
\hline \multicolumn{3}{|l|}{ Jenis Kelamin } \\
\hline Perempuan & 23 & 76,7 \\
\hline Laki-Laki & 7 & 23,3 \\
\hline \multicolumn{3}{|l|}{ Umur } \\
\hline $32-39$ & 3 & 10 \\
\hline $48-55$ & 15 & 50 \\
\hline $56-63$ & 7 & 23,3 \\
\hline \multicolumn{3}{|l|}{ Pekerjaan } \\
\hline Ibu Rumah Tangga & 16 & 53,3 \\
\hline Pedagang & 4 & 4 \\
\hline Wiraswasta & 1 & 3,3 \\
\hline $\mathrm{PNS} / \mathrm{TNI} / \mathrm{POL}$ & 4 & 13,3 \\
\hline Pensiunan & 2 & 6,7 \\
\hline Lain lain & 3 & 10 \\
\hline \multicolumn{3}{|l|}{ Keluarga yang sakit } \\
\hline Tidak & 14 & 46,7 \\
\hline Ada & 16 & 53,3 \\
\hline \multicolumn{3}{|l|}{ Status Gizi } \\
\hline Overweight & 16 & 53,3 \\
\hline Obes & 1 & 3,3 \\
\hline Obes Tk. I & 3 & 10 \\
\hline Obes Tk. II & 3 & 10 \\
\hline Normal & 6 & 20 \\
\hline At Risk & 1 & 3,3 \\
\hline \multicolumn{3}{|c|}{ Kadar Gula Darah } \\
\hline \multicolumn{3}{|l|}{ Sewaktu } \\
\hline \multicolumn{3}{|l|}{ Tinggi } \\
\hline Normal & 0 & - \\
\hline \multicolumn{3}{|l|}{ Kadar Gula Darah 2JPP } \\
\hline Tinggi & 24 & 80 \\
\hline Normal & 6 & 20 \\
\hline Kadar Gula Darah Pua & & \\
\hline Tinggi & 21 & 70 \\
\hline Normal & 9 & 30 \\
\hline Indeks Glikemik & & \\
\hline Tinggi & 15 & 50 \\
\hline Sedang & 15 & 50 \\
\hline
\end{tabular}

Pada tabel 1, menunjukkan bahwa sebagian besar responden berjenis kelamin perempuan dibandingkan laki-laki. Jenis 
kelamin merupakan salah faktor resiko yang menyebabkan terjadinya diabetes melitus dan faktor jenis kelamin adalah faktor yang tidak dapat dimodifikasi. Trisnawati (2013) menjelaskan bahwa kejadian Diabates melitus tipe 2 pada wanita lebih tinggi dibandingkan laki-laki. Lebih lanjut lagi dikatakan bahwa wanita lebih beresiko mengidap diabetes karena secara fisik wanita memiliki peluang lebih besar dalam peningkatan indeks masa tubuh. $^{11}$

Golongan umur terbanyak pada kelompok umur 48-55. Umur juga merupakan salah satu faktor resiko diabetes melitus yang tidak dapat dimodifikasi. Resiko untuk menderita intoleransi glukosa meningkat seiring dengan meningkatnya usia. Hal ini dikarenakan pada usia tersebut akan berkurangnya gerak badan dan masa otot namun berat badan semakin bertambah. ${ }^{7}$ Sebagian besar responden bekerja sebagai ibu rumah tangga.

Ditemukan adanya riwayat keluarga responden yang menderita penyakit diabetes melitus tipe 2 sebanyak 53,3\%. Penelitian yang dilakukan oleh Witasari dkk (2009) mengatakan bahwa DM merupakan penyakit keturunan, hal ini dikarenakan gen yang mengakibatkan tubuhnya tak dapat menghasilkan insulin dengan baik. Status kurang gizi atau kelebihan berat badan yang terjadi pada seseorang dapat meningkatkan resiko terkena penyakit diabetes melitus. ${ }^{15}$ Data yang diperoleh pada penelitian ini bahwa sebagian besar responden memiliki status gizi overweight. Seluruh responden memiliki kadar gula darah sewaktu dengan kategori tinggi, sedangkan untuk kadar gula darah 2 Jam Post Prandial (2 JPP) dan kadar gula darah puasa sebagian besar berada diatas batas normal. Untuk kandungan indeks glikemik menunjukkan bahwa pasien DM tipe-2 masing-masing mempunyai indeks glikemik tinggi dan sedang.

Berdasarkan grafik sebagaimana disajikan pada gambar 1, maka terlihat terjadi penurunan kadar gula darah responden dari kadar gula darah puasa (GDP) dan 2 Jam Post Prandial (2JPP) pada pasien DM tipe 2 dari kadar gula darah sewaktu (GDS).

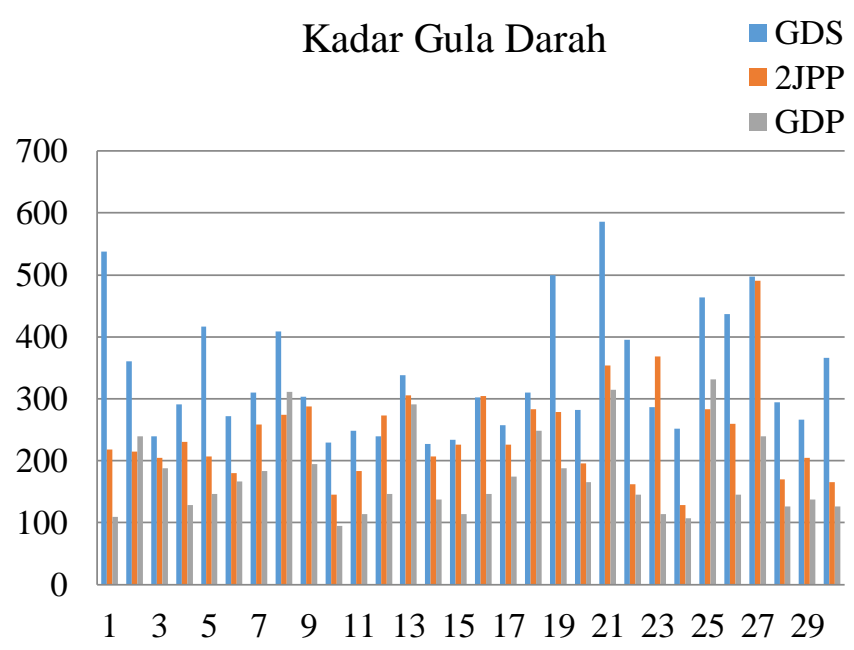

Gambar 1. Grafik kadar gula darah

Tabel 2. Hasil analisis variabel kandungan indeks glikemik dengan Kadar Gula Darah Puasa (GDP)

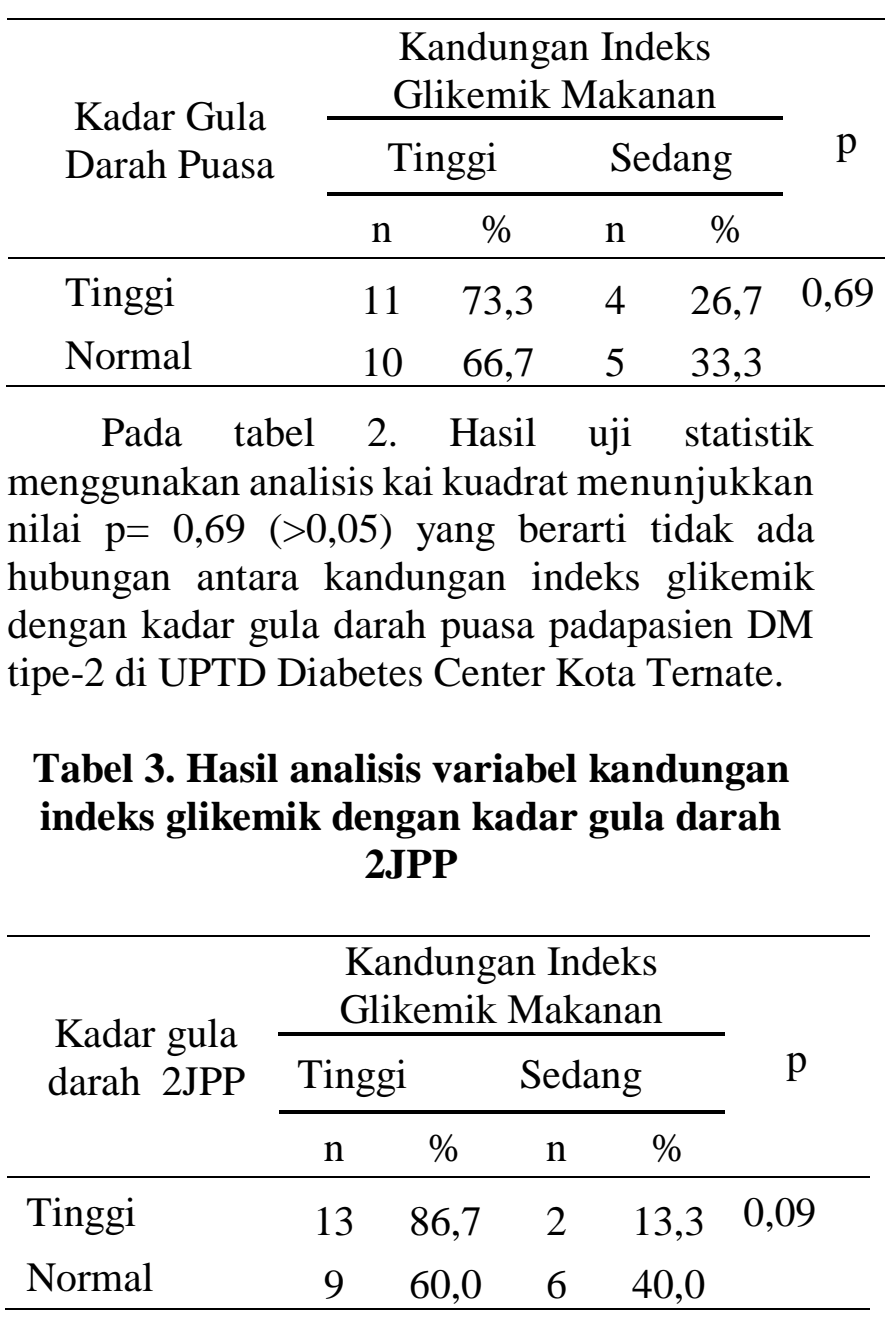


Pada tabel 3 terlihat bahwa hasil uji statistik menggunakan analisis kai kuadrat menunjukkan nilai $\mathrm{p}=0,09(>0,05)$ yang berarti tidak ada hubungan antara kandungan indeks glikemik dengan kadar glukosa darah 2 jam post prandial pada pasien DM tipe-2di UPTD Diabetes Center Kota Ternate.

\section{Tabel 4. Hasil Analisis Variabel Kandungan Indeks Glikemik Dengan Kadar Gula Darah Sewaktu (GDS)}

\begin{tabular}{lccccc}
\hline & \multicolumn{3}{l}{$\begin{array}{l}\text { Kandungan Indeks } \\
\text { Kadar gula }\end{array}$} & \multicolumn{3}{l}{\begin{tabular}{l} 
Glikemik Makann \\
\cline { 2 - 5 } darah sewaktu
\end{tabular}} & \multicolumn{2}{c}{ Tinggi } & \multicolumn{2}{c}{ Sedang } & \\
\cline { 2 - 5 } & $\mathrm{n}$ & $\%$ & $\mathrm{n}$ & $\%$ \\
\hline Tinggi & 15 & 50 & 15 & 50 \\
Normal & - & - & - & - \\
\hline
\end{tabular}

Pada tabel 4 terlihat bahwa seluruh responden memiliki kadar gula darah sewaktu kategori tinggi dengan kandungan indeks glikemik masing-masing tinggi dan sedang adalah $50 \%$. Secara statistik data untuk table 4 tidak dapat dianalisis karena terdapat 2 sel yang kosong dan data tidak terdistribusi normal.

Berdasarkan hasil uji statistik pada penelitian ini menunjukkan tidak ada hubungan antara konsumsi jenis makanan yang mengandung indeks glikemik tinggi dengan kadar gula darah puasa, kadar gula darah 2JPP dan kadar gula darah sewaktu pada pasien DM tipe-2 di Diabetes Center Kota Ternate. Sejalan dengan penelitian yang dilakukan oleh Wiardani dkk Tahun 2012 di RSUP Sanglah Denpasar, menyatakan bahwa berdasarkan hasil uji statistik Chi square tidak ada hubungan yang signifikan antara indeks glikemik menu makanan rumah sakit dengan pengendalian kadar gula darah pasien rawat inap. ${ }^{14}$

Berbeda dengan hasil penelitian lainnya dan teori yang menyimpulkan bahwa kandungan indeks glikemik suatu makanan dapat mempengaruhi kadar gula darah. Sejalan dengan penelitian yang dilakukan oleh Astuti dan Maulani tahun 2016, di Puskesmas Kota Jambi menunjukkan bahwa pangan indeks glikemik tinggi mempunyai hubungan yang signifikan terhadap kadar glukosa darah pasien DM tipe-2, dimana pasien DM tipe-2 yang mengkonsumsi pangan indeks glikemik tinggi memiliki glukosa darah yang tinggi. ${ }^{2}$ Seperti halnya penelitian yang dilakukan oleh oleh Rowa dkk 2014 di RSUD Salewangang Maros, diperoleh bahwa pasien yang diberikan diit DM rendah glikemik selama 7 hari menunjukkan adanya penurunan kadar gula darah sewaktu. ${ }^{9}$

Pada penelitian ini terlihat bahwa sebagian besar responden yang mengkonsumsi jenis pangan dengan kandungan indeks glikemik tinggi memiliki kadar gula darah puasa yang tinggi. Demikian juga pada kadar gula darah dua jam postprandial responden yang berada diatas batas normal seluruhnya mengkonsumsi jenis pangan dngan kandungan indeks glikemik tinggi. Sedangkan pada hasil pemeriksaan gula darah sewaktu ditemukan bahwa responden yang mengkonsumsi jenis pangan dengan kandungan indeks glikemik tinggi memiliki kadar gula darah yang tinggi dan responden yang mengkonsumsi jenis pangan dengan kandungan indeks glikemik sedang memiliki hasil pemeriksan gula darah yang rendah.

Berdasarkan hasil pemeriksaan kadar gula darah yang dilakukan oleh petugas laboratorium di Diabetes Center Kota Ternate pada grafik 1 menunjukkan adanya penurunan kadar gula darah 2JPP dan kadar gula darah puasa pada hari kedua pemeriksaan dibandingkan dengan hasil pemerisaan kadar gula darah sewaktu pada hari pertama. Hal ini dikarenakan adanya penyegaran kembali informasi terkait dengan pengelolaan penyakit diabetes melitus ketika melakukan wawancara yang kemudian dapat dikelola sendiri oleh responden terutama dalam hal pengaturan makan di rumah. Pemahaman yang kemudian muncul pada responden yang akan menentukan sikap atau respon nantinya terkait dengan pengaturan makan baik jadwal, jenis dan jumlah makanan yang dikonsumsi sehingga dapat mempengaruhi kadar gula darah responden. Hasil penelitian lainnya ditemukan bahwa faktor kepatuhan diet, konsumsi makanan tinggi karbohidrat, penyakit stres dan lainnya akan mempengaruhi gula darah yang tidak terkontrol. ${ }^{12}$ 
Berdasarkan hasil recall $3 \times 24$ jam terlihat sebagian besar responden mengkonsumsi jenis bahan makanan karbohidrat dalam jumlah banyak dengan kandungan IG $>70$ dan sehingga konsumsi zat gizi sudah melebihi dari kebutuhan tubuh. Terlihat juga bahwa status gizi responden sebagian besar adalah overweight meskipun mereka adalah pasien lama yang sering berkunjung di Diabetes Center Kota Ternate. Hal ini dapat mempengaruhi tingginya kadar gula darah pada pasien karena asupan karbohidratnya sudah lebih dari yang dianjurkan untuk pasien DM. Sejalan dengan penelitian yang dilakukan oleh Fitri dan Wirawanni (2012), yang menemukan bahwa rata-rata asupan energi dan karbohidrat pasien lebih tinggi dari anjuran untuk penderita DM. ${ }^{7}$ Seperti diketahui bahwa salah satu langkah penting dalam penatalaksanaan DM adalah terapi nutrisi medis (TNM). Penyandang DM perlu diberikan penekanan mengenai pentingnya keteraturan jadwal makan, jenis dan jumlah makanan dengan kandungan kalori yang dikonsumsi terutama pada pasien yang mengkonsumsi obat untuk meningkatkan sekresi insulin. ${ }^{12}$ Oleh karenanya pemberian edukasi harus selalu diberikan dengan tujuan memberikan pengetahuan sekaligus promosi hidup sehat sebagai bagian dari upaya pencegahan dan merupakan bagian yang sangat penting dalam pengeloaan DM secara holistik. Sebuah penelitian yang dilakukan oleh Bertalina dan Anindiyati (2016) ditemukan adanya hubungan yang bermakna antara pengetahuan tentang terapi diet dengan indeks glikemik bahan makanan yang dikonsumsi pasien DM tipe 2 di RUSD Dr. H.Abdul Moeloek Provinsi Lampung. ${ }^{6}$

Para ilmuwan telah menemukan bahwa kenaikan kadar glukosa darah diperkirakan dari makanan yang mengandung indeks glikemik tinggi, disamping indeks glikemik pangan perlu diperhatikan juga kandungan karbohidrat dari makanan karena akan mempengaruhi beban glikemik. ${ }^{17}$ Nilai IG produk pangan dipengaruhi oleh sejumlah faktor, antara lain kadar serat pangan, kadar amilosa dan amilopektin, kadar lemak dan protein dan cara pengolahan. Pengaruh faktor-faktor tersebut umumnya tidak berdiri sendiri, akan tetapi terdapat interaksi sehingga sulit menentukan faktor yang paling dominan yang dapat mempengaruhi nilai IG akhir. ${ }^{1}$

Indeks glikemik memberikan informasi mengenai kecepatan perubahan karbohidrat menjadi glukosa darah, tetapi tidak memberikan informasi mengenai banyaknya karbohidrat dan dampak pangan tertentu terhadap kadar glukosa darah. Beban glikemik (BG) dapat memberikan informasi mengenai pengaruh konsumsi pangan terhadap peningkatan kadar glukosa darah. Beban glikemik digunakan untuk menilai dampak konsumsi karbohidrat dengan memperhitungkan IG makanan. ${ }^{10}$ Semakin rendah kandungan karbohidrat semakin rendah beban glikemik maka semakin kecil suatu makanan yang disajikan memicu peningkatan kadar glukosa darah. Pada penderita DM diharapkan dapat memilih produk pangan yang akan dikonsumsi yang memiliki indeks glikemik rendah. ${ }^{1}$

Hasil pengumpulan data terlihat bahwa responden yang mengkonsumsi jenis makanan dengan kandungan indeks glikemik tinggi seluruhnya memiliki kadar gula darah sewaktu yang tinggi demikian juga dengan kadar gula darah puasa dan 2JPP hanya saja pada penelitian tidak bisa dibuktikan secara statistik hubungan antar variabel dikarenakan jumlah data responden tidak terdistribusi normal disetiap variabel.

\section{KESIMPULAN}

Secara statistik tidak menunjukkan terdapatnya hubungan signifikan antara konsumsi jenis makanan yang mengandung indeks glikemik tinggi dengan kadar gula darah puasa tinggi, kadar gula darah 2 jam pos prandial tinggi dan kadar gula darah sewaktu yang tinggi pada pasien DM tipe 2 di Diabetes Center Kota Ternate dikarenakan data tidak terdistribusi secara merata pada tiap sel yang diuji.

Saran, oleh karena itu maka diperlukan penelitian lanjutan untuk melihat variabel lain yang berhubungan dengan kadar gula darah dalam jumlah sampel yang lebih banyak dengan menggunakan desain penelitian yang berbeda. 


\section{KEPUSTAKAAN}

1. bin Arif A, Budiyanto A. Nilai Indeks Glikemik Produk Pangan dan Faktor-faktor yang Memengaruhinya. Jurnal Penelitian dan Pengembangan Pertanian. 2014;32(3):91-99.

2. Astuti A, Maulani M. Pangan Indeks Glikemik Tinggi dan Glukosa Darah Pasien Diabetes Tipe 2. Jurnal Endurance. 2017;2(2):225-231.

3. Bertalina B, Aindyati A. Hubungan Pengetahuan Terapi Diet dengan Indeks Glikemik Bahan Makanan yang Dikonsumsi Pasien Diabetes Mellitus. Jurnal Kesehatan. 2016;7(3):377-387.

4. RI F, Wirawanni Y. Asupan Energi, Karbohidrat, Serat, Beban Glikemik, Latihan Jasmani dan Kadar Gula Darah pada Pasien Diabetes Mellitus Tipe 2. Media Medika Indonesiana. 2012;46:121-131.

5. Gibney MJ. Gizi kesehatan masyarakat. In: Jakarta: Penerbit EGC; 2009.

6. PERKENI. Konsensus Pengelolaan dan Pencegahan Diabetes Melitus di Indonesia. 2011.

7. PERKENI. Konsensus Pengelolaan dan Pencegahan Diabetes Melitus di Indonesia. 2015.

8. Balitbangkes. Laporan Riset Kesehatan Dasar 2013 Provinsi Maluku Utara. Pertama. Jakarta: Badan Penelitian dan Pengembangan Kesehatan. Kementerian Kesehatan RI; 2013.

9. Rowa SS, Fanny L, Chaerunnimah. Identifikasi Penggunaan Bahan Makanan
Indeks Glikemik Rendah Dan Kadar Gula Pasien DM tipe 2 di RSUD Salewangang Maros. Jurnal Media Gizi Pangan. 2014;17(1):23-31.

10. Etik S. Asuhan Gizi Pada Diabetes Melitus, Ilmu Gizi Teori Dan Aplikasi. (Hardinsyah M, Supariasa, eds.). Jakarta: Penerbit Buku Kedokteran (EGC); 2017.

11. Trisnawati SK, Setyorogo S. Faktor risiko Kejadian diabetes melitus tipe II di puskesmas kecamatan cengkareng Jakarta Barat Tahun 2012. Jurnal Ilmiah Kesehatan. 2013;5(1):6-11.

12. Tsalissavrina I, Tritisari KP, Handayani D, Kusumastuty I, Ariestiningsih AD. Hubungan lama terdiagnosa diabetes dan kadar glukosa darah dengan fungsi kognitif penderita diabetes tipe 2 di Jawa Timur. AcTion: Aceh Nutrition Journal. 2018;3(1):28-33.

13. Wiardani NK, Ni Nyoman S, Yusi S. Indeks Glikemik Menu Makanan Rumah Sakit Dan Pengendalian Glukosa Darah Pada Pasien Diabetes Melitus Rawat Inap Di RSUP Sanglah Denpasar. Jurnal Skala Husada. 2012;9(1):44-50.

14. Witasari U, Rahmawaty S, Zulaekah S. Hubungan tingkat pengetahuan, asupan karbohidrat, dan serat dengan pengendalian kadar glukosa darah pada penderita diabetes melitus tipe 2. Jurnal Penelitian Sains \& Teknologi. 2009;10(2):130-138. 